\title{
Pengaruh Perasaan Gembira terhadap Kognitif Anak
}

\author{
Wahyutri Okfia ${ }^{1,(*)}$, Nur Hazizah ${ }^{1}$ \\ ${ }^{1}$ Jurusan Pendidikan Guru Pendidikan Anak Usia Dini, Fakultas Ilmu Pendidikan, \\ Universitas Negeri Padang, Padang, Indonesia \\ ${ }^{(*)}$ wahyutriokfia@gmail.com
}

\begin{abstract}
ABSTRAK
Kecerdasan emosi pada anak sangat perlu dikembangkan sedini mungkin agar anak dalam kehidupannya dapat mengelola emosinya, mampu mengenali perasaannya dan mengenali orang lain sehingga dari itu akan memudahkan anak bersosialisasi dan di terima baik oleh lingkungannya. Artikel ini dibuat untuk membahas pentingnya perasaan gembira dalam meningembangkan kognitif anak, dalam hal ini sangat diperlukan peran orang tua selaku pendidik pertama dan utama untuk mengembangkan kecerdasan emosi anak agar anak dapat berkembang kognitifnya dengan baik sehingga dari itu dapat mengetahui dan menjalankan peran sebagai orang tua dalam meninngkatkan rasa hgembira sebagai emosi yang positif pada anak yang dapat mengembangkan aspek kognitif nya.
\end{abstract}

Kata kunci : gembira, kecerdasan emosi, peran orang tua, kognitif

\section{PENDAHULUAN}

Emosi merupakan serangkaiana bentuk perasaan seseorang baik berupa perasaan baik maupun buruk. Emosi yang tidak terkendali pada dasarnya akan berdampak buruk pada diri anak terutama emosi yang negatif, dari ketidak terkendalian emosi ini, orang lain baik itu orang dewasa atau teman sebaya akan kurang tertarik padanya karena pada saat itu sikap anak prilaku anak akan membrutal dengan menangis sejadi jadinya bahkan akan memukul orang lain disekitarnya yang dianggap dampak dari timbulnya rasa marah atau emosi negatifnya. Sebaliknya anak yang mamapu mengendalikan emosinya dengan mengelola emosi dengan baik akan mendapat respon yang baik pula dari orang sekitar dan teman sebayanya.

Kekurang pahaman orang tua dan sebagian guru mengenai dampak dari emosi positif dan negatif saat ini akan sangat berpengaruh pada perkembangan anak selanjutnya. Saat ini banyak orang tua yang menunjukkan rasa sayang nya kepada anak dengan memberikan semua yang diinginkan anak sehingga anak tidak pernah merasakan kecekecewaan, padahal nantinya hal itu akan berdampak buruk kepada anak. Anak tidak akan bisa mengontrol emosinya dimasa mendatang sehingga jika sekali kecewa anak akan larut dalam kekecewaannya dan tak tau hal apa yang harus diperbuatnya untuk mengatasi masalah yang ia hadapi. 
Selain itu banyak guru yang lebih mengedepankan pembelajaran terhadap anak dibandingkan dengan bermain padahal pada masa ini bermain merupakan hal yang sangat disenangi anak dan sebagai guru hendaknya mampu m emasukkan pembelajaran dalam bermain dengan memberikan layanan yang baik pada anak saat bermain sehingga aspekaspek perkembangan anak dapat dicapai sesuai dengan tujuan.

Dengan berkembangnya suasana hati yang menyenangkan bagi anak, maka anak pun akan merasakan kegembairan dan mampu meningkatkan kecerdasan anak. Menurut Hazizah (2018) kecerdasan tak hanya bisa dilihat dari satu kemampuan melainkan bisa dilihat dari berbagai kemampuan yang dapat dilakukan anak. Adapun rasa gembira bisa dimunculkan dari banyak kegiatan baik itu bermain, bernyanyi, belajar dan bermain musik seperti yang dijelaskan Suyadi (2014) bahwa kecerdasan dari kecerdasan musikal seseorang akan dapat menyimpan nada, mengingat irama dan emosionalnya akan terpengaruhi oleh musik, sehingga musik dapat dikatan bahasa emosional yang dpat mempengaruhi hati seseorang. Namun, hal ini akan tergantung pada bagaimana cara guru mengolah pembelajaran atau permainan yang nantinya dapat membuat anak merasa gembira.

Maka dari itu tulisan ini dibuat bertujuan untuk mengetahui bagaimana pengaruh rasa gembira anak terhadap kecerdasan anak.

\section{KAJIAN TEORI}

Santrock dalam Qodariah (2017) menjelaskan bahwa emosi merupakan perasaan dari seseorang atau pengaruh yang ada setelah terjadi peristiwa atau interaksi yang penting dengan orang lain terutama yang melibatkan kesejahtraan bagi seseorang tersebut. Selanjutnya Nugraha (2008) mengemukakan emosi yaitu seluruh perasaan yang ada pada diri seseorang baik yang baik maupun yang buruk atau senang maupun tidak senang terhadap suatu peristiwa yang dialaminya. Ada tiga variabel mekanisme emosi yang dijelaskan Syamsuddin dalan Nugraha (2008) yaitu variabel stimulus adalah rangsangan/ stimulus yang diterima oleh seseorang yang dilihat oleh panca indranya yang nantinya akan menyebabkan seseorang emosi, selanjutnya variabel organismik yaitu perubahan yang terjadi di tubuh seseorang setelah panca indra melihat maka akan diteruskan de syaraf dan dari syaraf akan dikembalikan keseluruh tubuh sehingga akan terjadi perubahan ditubuh seseorang baik itu tekan darah naik, jantung berdetak cepat maupun lainnya, dan yang terakhir adalah variabel respon yaitu exspresi/ respon yang dimunculkan oleh seseorang setelah mengalami variabel stimulus dan organismik.

Nugraha $(2008)$ dalam bukunya
mengungkapkan bahwa setiap orang
memiliki emosi yang positif dan negatif seperti perasaan gembira dan marah. Hurlock (1978) mengemukakan gembira merupakan bentuk emosi yang menyenangkan seseorang yang dapat diexspresikan dengan tertawa ataupun tersenyum. Setiap orang memiliki intensitas perasaan gembira yang berbeda begitu juga dengan kecerdasan karena setiap anak memiliki keunikan tersendiri. Seperti yang dikemukakan Tony Buzan dalam Hazizah (2018) kecerdasan merupakan kemampuan seseorang dalam berfikir baru yang memunculkan hasil beda dan berani tampil beda.

Orang yang cerdas akan selalu bisa mengatasi permasalahan yang ia hadapi karena ia akan berfikir kreatif dan memunculkan ide-ide yang baru. Oleh karena itu sangat diharapkan peran orang tua juga guru dalam pemberian stimus yang tepat agar 
anak dapat berkembang dengan cerdas (Hazizah, 2017)

Suyadi (2014) mengemukakan bahwa kecerdasan emosional itu dapat memotivasi diri sendiri, bertahan dari frustasi, mengelola emosi atau perasaan tidak berlebihan dalam mengekspresikan perasaannya, dan dapat menjaga beban stres tidak melumpuhkan kemampuan berfikir. Untuk itu bahwa suasana emosi yang positif yaitu senang atau gembira dapat meingkatkan keberhasilan dalam belajar.

Kemampuan anak untuk mengelola emosinya merupakan hal yang penting dalam perkembangan emosinya seperti yang dikemukakan Graziano dalam Wandansari (2017) bahwa anak yang mampu mengelola emosinya dengan efisien maka anak tersebut dalam proses transisi dan nantinya dapat mengembangkan akademiknya. Untuk itu peran guru dalam hal pengembangan dan pengelolaan emosi pada anak sangat penting agar anak mampu mengelola emosi sekaligus meningkatkan akademik nya.

Namun dalam hal ini orang tua tak kalah penting perannya karena orang tua lah yang merupakan guru pertama bagi anakanak seperti yang dikemukakan oleh Halberstad \& Lozada dalam Wandansaria (2017) bahwa yang memainkan peran utama dalam pendidikan adalah orang tua. Pengembangan emosi yang dilakukan orang tua terhadap anak dengan cara berkomunikasi dengan anak sejak bayi dan menenangkannya dan mengembangkan kemampuan anak sehingga mampu mengenali dan menanggapi exspresi emosi dari orang tua sehingga nantinya hal tersebut akan menjadi kebiasaan bagi anak dan anak dapat mengenali exspresi emosi ditahap perkebangan selanjutnya.

( Moh, 2017) mengatakan bahwa seseorang yang memiliki kecerdasan akademik tanpa dibarengi dengan kecerdasan sosial emosional tidak akan menjamin kesuksesan dalam hidupnya untuk itu, kecerdasan intelektual dan sosial emosional dalam diri seseorang harus seimbang karena jika kecerdasan intelektual dan sosial emosional tidak seimbang tidak akan menghasilkan apa-apa. Jika anak distimulus untuk mengembangkan sosial emosional dalam hidupnya maka anak akan mampu bersosialisasi dengan baik dan mudah diterima oleh lingkungannya.

Adapun untuk memperoleh hal tersebut hendaknya anak memiliki kecerdasan interpersonal dan intra personal sehingga dalam sosialisasinya akan mendatangkan manfaat yang baik yang mampu meningkatkan berbagai macam kecerdasan anak. Kecerdasan interpersonal adalah kemampuan seseorang dalam mengenali orang lain yang ada disekitarnya mampu berhubungan dengan orang lain sehingga dari kecerdasan ini akan membuat seseorang memiliki kepekaan hati yang dapat berempati dan tidak menyinggung perasaan orang lain saat berinteraksi (Sayudi, 2014: 133). Kecerdasan intrapersonal yaitu kemampuan seseorag mengenali dirinya sendiri juga bertanggung jawab atas dirinya, sehingga dari kecerdasan ini seseorang tidak akan menggantungkan dirinya kepada orang lain dan mampu memotivasi dirinya untuk bangkit dan meraih tujuan hidupnya secara mandiri (Sayudi, 2014: 133).

Seiring dengan yang dikemukakan oleh Nugraha (2008) bahwa orang yang secara emosi memiliki kemamampuan mengenali dirinya dan perasaannya sendiri serta memahami dan mengenali perasaan orang lain akan memiliki keuntungan dalam hidupnya. Seseorang yang emosinya baik atau berkembang akan berkemungkinana memperoleh kebahagiann karena emosi yang baik akan menguasai pikiran dan mendorong kearah produktivitasnya sehingga dari itu akan diperoleh keberhasilan dalam hidupnya.

Wijanarko (2012) megatakan bahwa untuk menciptakan anak yang cerdas salah 
satu caranya adalah dengan menyelesaikan masalah emosi anak yaitu:

\section{a. Gambar diri}

Sebagai orang tua hendaknya mampu bersyukur dengan dirinya, mengenali sisi positif yang ada padanya sehingga mampu berucap hal yang positif dengan itu akan dapat menumbuhkan citra diri anak, jika anak gagal dalam melakukan sesuatu, jangan fokus pada sisi negatif atas kegagalan anak tersebut karena hal itu akan menjadikan anak minder dan tidak akan senang hati dan otak nya tidak akan maksimal.

b. Rasa aman

Sebagai orang tua hendaknya mampu memberi perhatian yang penuh memberi sentuhan kasih sayang agar anak merasa aman, terima anak apaanya karena hal itu akan memaksimalkan otak anak dan jika ingin menghukum anak, maka anak harus tau alasan mengapa ia dihukum adil dan konsisten.

Untuk mengatasi emosi anak harus dimulai dari orang tua karena orang tua lah yang merupakan pondasi dari perkmbangan anak jika orang tua mampu mengembangkan emosi yang positif bagi anak maka pada anak akan menghasilkan hormon yang positif sehingga darinya akan perkembangan otak anak akan maksimal sehingga dapat mencerdaskan anak.

\section{PEMBAHASAN}

Setiap anak memiliki emosi yang positif dan negatif dalam dirinya, terlihat saat anak ada anak yang tertawa terbahak-bahak dikarenakan adanya stimulus yang menyebabkan ia tertawa namun pada kenyataannya setiap anak memiliki intensitas gembira yang berbeda sehingga terkadang nampak anak yang mengekspresikan rasa gembiranya terhadap stimulus yang diberikan berbeda anak anak yang tertawanya sangat terbahak-bahak pada satu situasi namun ada pula anak yang hanya tersenyum melihat situasi tersebut hal ini sejalan dengan yang dikemukakan oleh Nugraha (2008) dalam bukunya mengungkapkan bahwa setiap orang memiliki emosi yang positif dan negatif seperti perasaan gembira dan marah. Hurlock (1978) Setiap orang memiliki intensitas perasaan gembira yang berbeda begitu juga dengan kecerdasan karena setiap anak memiliki keunikan tersendiri.

Begitu juga dengan kecerdasan bahwa setiap anak bisa saja memiliki kecerdasan yang berbeda seperti yang sering dilihat bahwa tak smua anak mampu menyelesaikan sutu permasalahan dengan baik dan cepat saat menyusun puzzle dengan waktu yang bersamaan anak yang mampu mengeontrol emosi nya dengan tenang lebih cepat menyelesaikan permasalahan karena anak akan lebih tenang berfikir sehingga dapat menghasilkan pemikiran yang baru serta kreatif dalam menyuzun puzzle dibandingkan dengan anak yang terburu-buru karena kurang mampu mengontrol emosinya. Orang yang cerdas akan selalu bisa mengatasi permasalahan yang ia hadapi karena ia akan berfikir kreatif dan memunculkan ide-ide yang baru (Hazizah, 2017).

Oleh sebab itu hendak nya sebagai guru mampu memberikan stimulus-stimulus yang akan membuat anak lebih mampu dalam pengontrolan emosinya agar tetap dalam keadaan tenang dan senang saat belajar sehingga akan mengehasilkan pemikiran yang lebih baik.

Penomena yang terjadi adalah banyaknya orang tua yang kurang memahami pentingnya kecerdasan emosi pada anak sehingga orang tua lebih mengedepankan 
akademik-akademik pada anak tanpa mempertimbangkan apakah anak tersebut akan merasakan senang, gembira. padahal orang tua hendaknya lebih menyeimbangkan penstimulusan anak mengenai kecerdasan emosi dengan kognitif karena dari kecerdasan emosi ini anak dapat mengenal dirinya dan juga orang lain sehingga dari itu anak akan lebih banyak bersosialisasi dan memperoleh pengetahuan dan merasakan hal yang menyenangkan dari hal tersebut. Sejalan dengan yang dikemukakan Moh (2017) mengatakan bahwa seseorang yang memiliki kecerdasan akademik tanpa dibarengi dengan kecerdasan sosial emosional tidak akan menjamin kesuksesan dalam hidupnya untuk itu, kecerdasan intelektual dan sosial emosional dalam diri seseorang harus seimbang karena jika kecerdasan intelektual dan sosial emosional tidak seimbang tidak akan menghasilkan apa-apa. Jika anak distimulus untuk mengembangkan sosial emosional dalam hidupnya maka anak akan mampu bersosialisasi dengan baik dan mudah diterima oleh lingkungannya. Graziano dalam Wandansari (2017) bahwa anak yang mampu mengelola emosinya dengan efisien maka anak tersebut dalam proses transisi dan nantinya dapat mengembangkan akademiknya.

Pada masa sekarang ini banyaknya orang tua yang memarahi bahkan mencap anak nya sebagai anak yang bodoh jika anak nya melakukan kesalahan bahkan ada yang mencap anak nya bandel dan hal itu dilakukan dengan berulang-ulang tanpa memikirkan bahwa anak akan merasakan sedih, kecewa. Dan hal itu akan berdampak pada otak anak apalagi anak usia dini bahkan nantinya akan mampu mematikan sel syaraf anak. Hendaknya sebagai orang tua mampu mengucapkan hal-hal yang positif yang dapat memotivasi anak agar anak dapat berubah dari kesalahan yang diperbuatnya sehingga akan mampu mempengaruhi kualitas otak anak dan bahkan hal tersebut akan lebih menjadikan anak merasa aman nyaman dan bahagia karena ia akan merasakan bahwa orang tuanya sangat menyayanginya seperti yang dikatakan Wijanarko (2012) megatakan bahwa untuk menciptakan anak yang cerdas salah satu caranya adalah dengan menyelesaikan masalah emosi anak yaitu: Gambar diri dimana sebagai orang tua hendaknya mampu bersyukur dengan dirinya, mengenali sisi positif yang ada padanya sehingga mampu berucap hal yang positif dengan itu akan dapat menumbuhkan citra diri anak, jika anak gagal dalam melakukan sesuatu, jangan fokus pada sisi negatif atas kegagalan anak tersebut karena hal itu akan menjadikan anak minder dan tidak akan senang hati dan otak nya tidak akan maksimal. Sebagai orang tua hendaknya mampu memberi perhatian yang penuh memberi sentuhan kasih sayang agar anak merasa aman, terima anak apaanya karena hal itu akan memaksimalkan otak anak dan jika ingin menghukum anak, maka anak

Nugraha (2008) bahwa orang yang secara emosi memiliki kemamampuan mengenali dirinya dan perasaannya sendiri serta memahami dan mengenali perasaan orang lain akan memiliki keuntungan dalam hidupnya. Seseorang yang emosinya baik atau berkembang akan berkemungkinana memperoleh kebahagiann karena emosi yang baik akan menguasai pikiran dan mendorong kearah produktivitasnya sehingga dari itu akan diperoleh keberhasilan dalam hidupnya.

Sesuai dengan yang pernah saya lihat bahwa anak yang perasaannya dalam keadaan senang, gembira lebih cepat dalam memproses informasi yang diterima saat memperhatikan anak yang sedang bermain dengan ibunya yang permainannya jika dipandang dengan sebelah mata hanya lah permainan kecil yang saya rasa itu diciptakan sendiri oleh ibunya yaitu anak menaiki kaki ibunya lalu berjalan bersama yang saat bermainnya ibu memasukkan unsur 
berhitung sehingga dari permainan tersebut anak terlihat sangat gembira dan bahagia dan alhasil anak dapat berhitug 1 sampai 5 dengan permainan tersebut. Dapat saya simpulkan bahwasanya keadaan emosi anak yang gembira sangat mempengaruhi kognitif anak karena anak belajar dalam bermain yang menyenangkan baginya.

\section{KESIMPULAN}

Dari artikel yang sudah dibuat ini dapat disimpilkan bahwa:

1. Setiap anak memiliki tingkatan emosi yang berbeda, emosi yang positif yaitu gembira dapat meningkatkan kognitif anak

2. Sebagai orang tua hendaknya dapat memahami kecerdasan emosi agar dapat memberikan stimus pada anak mengenai kecerdasan emosi, sehingga dapat pula menyeimbangkan antra kecerdasan emosi dengan akademik.

\section{REFERENSI}

Hazizah, N. (2018). The Importance of Playing for Developing Intelligence in Early Childhood, 169(Icece 2017), 213215.

Hurlock, Elizabeth B. (1978). Perkembangan Anak. jakarta: Erlangga

Moh, A. (2017). The Development of Children's Social-Emotional Competences: A Case Study in UNP's Labschool-Kindergarten, Padang Indonesia, 58, 369-374.

Nugraha, Ali. (2008). Metode Pengembangan Sosial Emosional. Jakarta: Universitas Terbuka.

Qodariah, L., \& Pebriani, L. V. (2017). Recognizing Young Children's Expressive Styles of Emotions (2-6 Years Old).
Suyadi. (2014). Teori Pembelajaran Anak Usia Dini Dalam Kajian Neurosains. Bandung: PT Remaja Rosdakarya.

Wandansari, Y., Retno, D., \& Afiatin, T. (2017). Optimizing the Development of Emotional Competence in Early Childhood, 58, 475-481.

Wijanarko, jarot. (2012). Multiple Intelligences Anak Cerdas. Banten: PT. Happy Holly Kids. 